\title{
Potential distribution of margay (Leopardus wiedii, Schinz 1821) in Northeastern Mexico
}

\author{
Jesús Manuel Martínez-Calderas ${ }^{1}$, Anuar David Hernández-Saintmartín' ${ }^{1}$, Octavio César Rosas-Rosas ${ }^{1}$, Jorge Palacio- \\ Núñez ${ }^{1^{*}}$, Jorge Agustín Villordo-Galván² and Alejandra Olivera-Méndez ${ }^{1}$
}

\begin{abstract}
${ }^{1}$ Colegio de Postgraduados, Campus San Luis Potosí. Iturbide 73, Salinas de Hidalgo 78622, San Luis Potosí, México. E-mail: biologo99mx@yahoo.com.mx (JMM-C), anuarhernandez@gmail.com (ADH-S), octaviocrr@colpos.mx (OCR-R), jpalacio@colpos.mx (JP-N), aleolivera@colpos.mx (AO-M).

${ }^{2}$ Departamento de Ciencias Biológicas. Universidad Popular Autónoma del Estado de Puebla (UPAEP). Calle 21 Sur 1101. Col Santiago, 72410. Puebla, México. E-mail: agusvillo@hotmail.com (JAV-G).

${ }^{*}$ Corresponding author
\end{abstract}

The margay (Leopardus wiedii, Schinz 1821) is a small Neotropical cat that is native with distribution from South America into Northeastern Mexico. This species is now threatened by illegal hunting and habitat destruction and, in Northeastern Mexico, their habitat has been fragmented and population sizes have been dramatically reduced. We use the MaxEnt algorithm to model the potential distribution of this elusive species, based on trustable presence records and information about their habitat condition. The aim of this study was to estimate the potential distribution of margays in Northeastern Mexico. We determined potential distribution in the physiographic subprovinces (PSP) of Llanuras y Lomerios, Gran Sierra Plegada and Carso Huasteco. A model was generated using recent and historical records through the MaxEnt algorithm. We used four records from online databases, 36 from literature and 13 from our own fieldwork, as well as 27 predictive variables: 19 associated with climate, two with land use and vegetation type, four associated with topography and two with anthropogenic effects. Seven variables contributed to over $90 \%$ of the distribution model and were highly predictive (AUC $=0.964)$. The potential distribution of margay represents $9.0 \%\left(7,607 \mathrm{~km}^{2}\right)$ of the area, which is highly fragmented. The PSP Gran Sierra Plegada and Carso Huasteco showed the widest distribution range. The four most relevant variables were: precipitation of the most humid quarter, vegetation type, and both altitude and topographic indexes. We applied species distribution modeling by incorporating recent information collected through fieldwork and surveys as well as historical records in order to predict the margay's potential distribution in Northeastern Mexico. We obtained a robust model based on the most relevant bioclimatic and landscape variables. The landscape in this region is highly fragmented and the largest continuous areas were located in the roughest and inaccessible landscape of the mountainous localities of Gran Sierra Plegada and Carso Huasteco, where an important portion of these PSP maintains continuity in the area of the potential distribution of the margay. Very little is known of the status and abundance of the margay and this study complements our current knowledge of this species in Northeastern Mexico and provides important information regarding the quality of the habitat in this portion of the country. There are several current threats that are being caused by changes in land use in Northeastern Mexico and other parts of their distribution, and this information is essential to establish conservation plans for this species and their habitat. More studies assessing potential distribution throughout their range are needed to support adequate conservation efforts.

El tigrillo o margay (Leopardus wiedii, Schinz 1821) es un pequeño felino Neotropical nativo con distribución desde Suramérica hasta el noreste de México. Esta especie se encuentra amenazada por cacería ilegal y por la destrucción de su hábitat. En el noreste de México sus hábitat están fragmentados y su población está reduciendo dramáticamente. Para obtener un modelo de distribución potencial de esta especie se usó el algoritmo MaxEnt, basado en registros confiables de presencia, así como información sobre la condición de su hábitat. El objetivo del presente estudio fue estimar la distribución potencial del tigrillo en el noreste de México. La distribución potencial se realizó en las subprovincias fisiográficas (PSP) Llanuras y Lomerìos, Gran Sierra Plegada y Carso Huasteco. Se generó un modelo mediante el uso de registros históricos y actuales mediante el algoritmo MaxEnt. Se usaron cuatro registros de bases de datos en línea, 36 de la literatura y 13 de trabajo de campo propio. También se usaron 27 variables predictoras: 19 climáticas, dos de uso del suelo y vegetación, cuatro asociadas a topografía y dos asociadas a efectos antrópicos. Siete variables contribuyeron en más del $90 \%$ del modelo de distribución, el cual fue buen predictor (AUC $=0.964)$. La distribución potencial del tigrillo fue del $9.0 \%$ del área de estudio $\left(7,607 \mathrm{~km}^{2}\right)$, la cual se encontró altamente fragmentada. Las PSP Gran Sierra Plegada y Carso Huasteco mostraron el rango de distribución más amplia. Las cuatro variables más relevantes fueron: precipitación del trimestre más húmedo, tipo de vegetación, altitud e índice topográfico. Se aplicó un modelo de distribución de especie con la incorporación de información reciente, colectada de trabajo de campo propio y encuestas, así como de registros históricos, con el propósito de predecir la distribución potencial del tigrillo en el noreste de México. Se obtuvo un modelo robusto con base en las variables más relevantes tanto bioclimáticas como del hábitat. El paisaje en esta región se encontró altamente fragmentado, donde las mayores aéreas se localizaron en zonas 
de pendiente rugosa e inaccesibles en las localidades montañosas de Gran Sierra Plegada y Carso Huasteco, donde una porción importante de estas PSP mantienen una continuidad de distribución potencial del tigrillo. Muy poco se sabe sobre el estatus y la abundancia del tigrillo y este estudio complementa el conocimiento sobre esta especie en el noreste de México, y provee información importante sobre la condición del hábitat en esta porción del país. Existen varias amenazas, básicamente por cambios en el uso del suelo en el noreste de México y otras partes de su distribución, y esta información es necesaria para establecer planes de conservación para esta especie y su hábitat. Se necesitan más estudios en los que se evalué el grado de distribución potencial en toda el área para establecer planes adecuados de conservación.

Key words: connectivity; habitat fragmentation; MaxEnt; Tropical habitats; Wild felids.

C 2016 Asociación Mexicana de Mastozoología, www.mastozoologiamexicana.org

\section{Introduction}

The margay (Leopardus wiedii, Schinz 1821) is widely distributed in South and Central America to its northernmost distribution extending into Northeastern Mexico (Hall 1981; Aranda 2005). Basic information on the abundance and distribution of margays in this area and the rest of country is poorly understood. Several studies mention that the margay is closely linked to forest habitats, especially in tropical and subtropical areas because it is generally considered to be more arboreal and better adapted to live in trees than other cat species (Bisbal 1989; Oliveira 1998). This makes it more vulnerable to deforestation (Tewes and Schmidly 1987) and, in Mexico, this felid is listed as endangered on the NOM-059 SEMARNAT-2010 (SEMARNAT 2010), although internationally it is considered as threatened (Payan et al. 2008). The habitat of this species is being destroyed or converted to agriculture and other land uses along its entire distribution and new studies suggest that its abundance is lower than previously thought. Therefore, it is crucial to generate potential species distribution models to be used as a baseline for the future conservation efforts of the margay (Ferrier and Guisan 2006; Payan et al. 2008; Oliveira et al. 2010).

Today, the use of algorithms in the development of predictive and potential species distribution models has increased. Potential distribution is calculated from georeferenced observations and variables that act as predictors. Thanks to its predictive capacity and robustness in generating species distribution models, one of the most widely used algorithms is MaxEnt (Elith et al. 2006; Phillips et al. 2006). This algorithm generates distribution probabilities for the concerned species in a particular region, based on different variables that can be environmental (climate, vegetation type, topography), demographic or anthropogenic. It is constructed exclusively on current conditions present in the localities where the species occurs (Elith et al. 2006; Pearson et al. 2007). The software determines the distribution through the adjustment of the species occurrence probability in pixels throughout the study area. This is based on the idea that the best possible explanation for an unknown phenomenon maximizes the entropy or uncertainty of the distribution of the probability, depending on certain limitations. Concerning potential distribution models, they consist of values of those pixels in which the species has been detected (Phillips et al. 2004; Phillips et al. 2006). This study is part of a regional project on the ecology and conservation of wild felids in Mexico, and its purpose was to estimate the potential distribution of margays (Leopardus wiedii) in Northeastern Mexico.

\section{Methods}

Study area. The study area partially covers two physiographic provinces $\left(84,523 \mathrm{~km}^{2}\right)$ : Sierra Madre Oriental and Llanura Costera del Golfo Norte. In the first, it included part of the physiographic subprovinces Gran Sierra Plegada (GSP) and Carso Huasteco (CH). In the second, only the subprovince 
Llanuras y Lomerios (LL) was partially included (Figure 1). The characteristics of these subprovinces have great relevance in the landscape structure and degree of conservation. While in LL there is great antrophogenic impact throughout its surface due to topographic conditions, in $\mathrm{CH}$, and mostly in GSP, large remnants of habitat remain in good condition. In this region, topography is flat to undulating towards the East and rough towards the West, with a wide range of climatic conditions from tropical to temperate, that varies from humid to semidry. There is a clear seasonal variation regarding precipitation, as well as a clear difference between the amount of rainfall in one region and the other. Altitude ranges from 0 to 2,300 $\mathrm{m}$ and precipitation from 600 to 2,500 $\mathrm{mm}$.

Anthropic land use is widespread within the study area for farming, agriculture and, in some regions, wood extraction (INEGI 2002a). The types of land use and vegetation are shown on Table 1. In this study there are 6 groups of native vegetation (NV) subdivided into 18 categories according to humidity and latitude gradients (Table 1). In GSP, the landscape corresponds to a mountainous karstic rock mass with irregular intermontane valleys, where anthropic use predominates (46.18 $\%)$. The native vegetation in GSP is dominated by tropical dry (26.99\%), followed by temperate $(20.98 \%)$ vegetation. Drier $(2.86 \%)$ and more humid tropical $(1.02 \%)$ types of vegetation are scarce. The landscape in $\mathrm{CH}$ is characterized by abrupt karstic mountains and intermontane valleys; anthropic use is $41.14 \%$, dominated by dry tropical (20.49\%) and dry (16.25\%) vegetation, followed by temperate vegetation $(15.98 \%)$. In $\mathrm{LL}$, the terrain ranges from flat to undulated, where anthropic use is $50.86 \%$ and dry tropical vegetation predominates ( $25.28 \%)$, followed by temperate vegetation (18.08\%). Tropical humid (3.16\%) and dry (0.47\%) vegetation are scarce; other types of vegetation such as cattail marshes, palm forests, and riparian vegetation occupy $2.15 \%$ of the landscape.

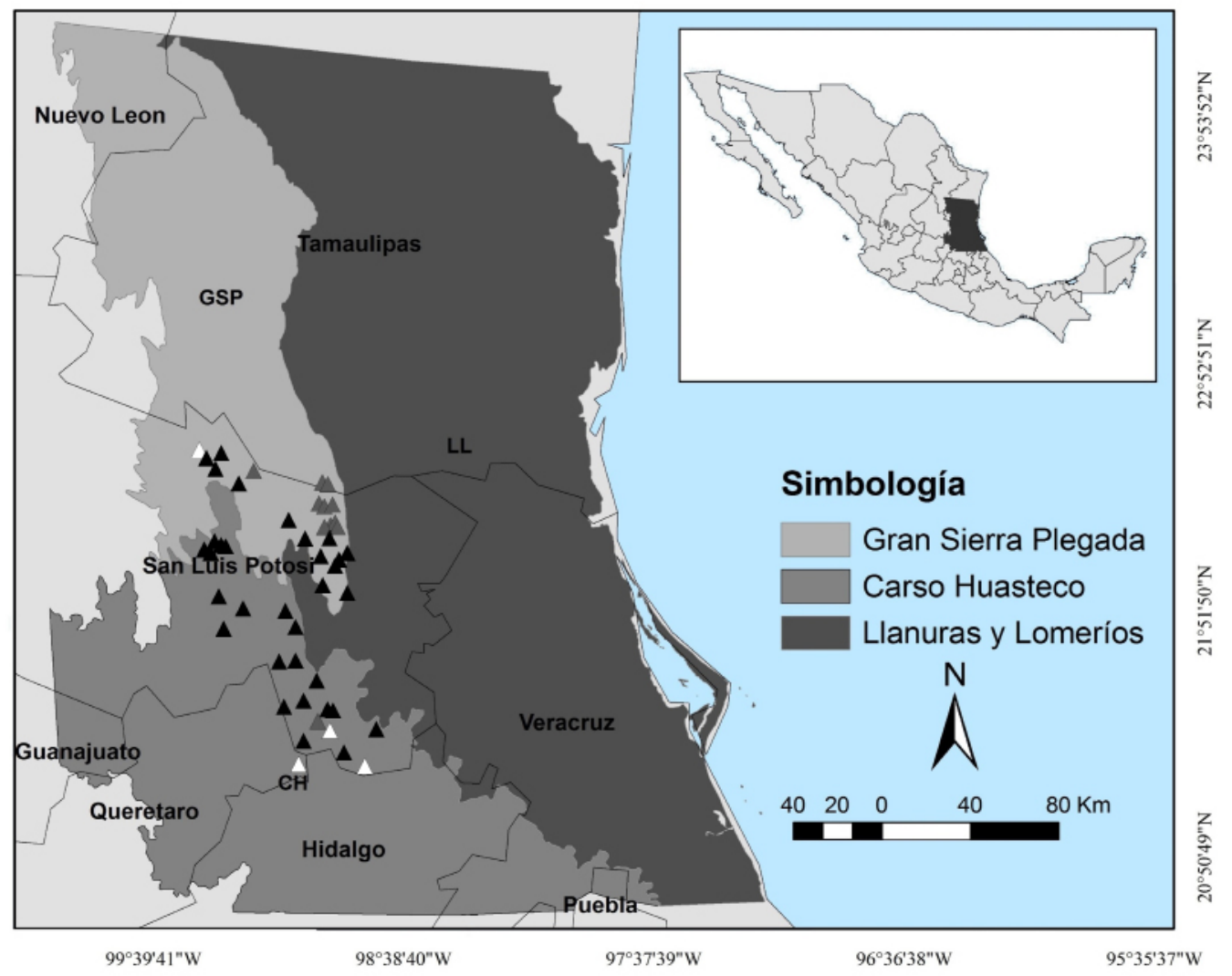

Figure 1. Study area with the location of physiographic subprovinces and margay records in Northeastern Mexico, which including portions of the states of Nuevo León, Tamaulipas, San Luis Potosí, Veracruz, Guanajuato, Querétaro, Hidalgo, and Puebla. The white triangles are historical records, blacks are the literature records (Martínez-Calderas et al. 2012), and grays are of fieldwork and surveys records. 
Table 1. Percentage by subprovince of Type of anthropic land use and native vegetation (NV) in Gran Sierra Plegada (GSP); Carso Huasteco $(\mathrm{CH})$ and Llanuras y Lomerios (LL) of Northeastern Mexico.

\begin{tabular}{llrrr}
\hline \multicolumn{1}{c}{ Category } & \multicolumn{1}{c}{ Land use and vegetation type } & GSP & CH & LL \\
\hline Anthropic use & Agriculture & 18.89 & 16.71 & 19.34 \\
& Urban area & 0.50 & 0.48 & 0.45 \\
& Induced vegetation & 26.79 & 23.95 & 31.07 \\
& Desert shrub & 2.86 & 15.97 & 0.29 \\
& Grassland & 0.00 & 0.13 & 0.00 \\
& Halophyte vegetation & 0.00 & 0.15 & 0.18 \\
NV Temperate & Oak forest & 10.28 & 7.82 & 9.30 \\
& Oak-pine forest & 3.82 & 2.91 & 3.46 \\
& Pine-oak forest & 2.93 & 2.24 & 2.65 \\
& Pine forest & 0.92 & 0.70 & 2.65 \\
& Clouded forest & 2.40 & 1.82 & 0.00 \\
& Juniperus forest & 0.63 & 0.48 & 0.00 \\
& Abies forest & 0.00 & 0.01 & 0.02 \\
NV Tropical dry & Tamaulipan thorn scrub & 0.00 & 0.00 & 0.98 \\
& Semitropical thorn scrub & 11.20 & 8.52 & 10.14 \\
& Tropical deciduous forest & 13.77 & 10.48 & 12.46 \\
& Tropical thorn forest & 1.88 & 1.43 & 1.70 \\
& Tropical semi-deciduous forest & 0.14 & 0.06 & 0.00 \\
& Subperennifolia tropical forest & 1.02 & 1.32 & 0.92 \\
& Tropical rain forest & 0.00 & 1.88 & 2.24 \\
& Other (popal, mangrove forest, cattail marshes, etc.) & 1.97 & 2.94 & 2.15 \\
\hline \multirow{3}{*}{ NV Other } & & & &
\end{tabular}

Data collection and modeling. The information used for the development of the model was obtained from several sources. Thirty-six records come from a previous study (Martínez-Calderas et al. 2012), 13 were obtained through fieldwork with random camera-trapping sessions between August 2010 and March 2012, and four are georeferenced historical records (prior to the year 2000), obtained from the GBIF (Global Biodiversity Information Facility) database provider (GBIF 2014).

For modeling, 27 predictive variables were used: 19 bioclimatic (Hijmans et al. 2005), two of vegetation (Hansen et al. 2000; INEGI 2002b), four derived from the digital elevation model (INEGI 2008), and two anthropic (CIAT etal. 2005; INEGI 2005). In order to generate the potential distribution model, we used the algorithm software MaxEnt (version 3.3.3k), which is based on a maximum entropy algorithm (Phillips et al. 2006). We used the method reported by Martínez-Calderas et al. (2015) for the realization of the model. The same methods were also successfully implemented in that study for ocelots. Default settings were: maximum number of background points $=10.000$, regularization multiplier $=1$, replicates $=20$, replicate run type $=$ bootstrap, convergence threshold $=0.00001$, and maximum number of iterations $=10000$. From the occurrence data, $70 \%$ was selected randomly as training data and $30 \%$ as the test data set. We used the logistic output of MaxEnt with prediction values ranging from 0 (unsuitable habitat) to 1 (optimal habitat). To validate the performance of the model, the weight of the omission error and the commission error equally, we considered the area under curve (AUC), which is generated by the algorithm (Hernandez et al. 2006) and is obtained directly from the evaluation of the models through ROC curves (Receiver Operating Characteristic; e. g. Contreras-Medina et al. 2010). Moreover, variables in the model are assessed through a jackknife test that compares the models with all possible combinations of 
environmental variables by measuring the importance of the variable. This expressed the relative importance of every predictor variable separately in order to determine the percentage that each one provides to the model. The results obtained from the model in ASCII format were processed and reclassified using ArcGIS 9.2 (ESRI 2006). The binary map (absence-presence) for the potential distribution of the margay was generated (Figure 2) considering the average map that represents the induced and adjusted habitat of the species (Anderson et al. 2003; Burneo et al. 2009). We used the minimum presence training as threshold reclassification (0.2745). Finally, using this map and levels, we calculated the potential distribution area shown in percentage of the total area of each physiographic subprovince.

\section{Results}

The margay was recorded in diverse environmental conditions within the study area, in locations varying from very humid to semidry environments (Appendix 1). Regarding temperature, this species inhabit from very hot to temperate, and in an altitude ranging from 6 to 1,800 m (INEGI 2002b; INEGI 2008; INEGI 2011). Seven predictive variables explained $94.4 \%$ of the model, showing an AUC of $0.964 \pm$ 0.0097, where an AUC value higher than 0.9 indicates an excellent model (Araujo and Guisan 2006). The four most relevant variables were: precipitation of the most humid quarter, vegetation type, and both altitude and topographic indexes. Each of the other three remaining variables did not account for more than $3 \%$ of the total contribution (Table 2).

The potential distribution area of the margay in Northeastern Mexico covered approximately $9 \%$ of the total studied landscape, with an area of 7,607 $\mathrm{km}^{2}$. GSP and $\mathrm{CH}$ subprovinces showed the highest distribution, with a potential presence of 18.1 and $20.2 \%$ on each surface, respectively. Conversely, LL accounted for only $0.4 \%$ (Table 3). The highest potential distribution continuity was observed in the contiguous mountainous areas between GSP and $\mathrm{CH}$. In all of $\mathrm{LL}$, we only found small and isolated patches due to fragmentation (Figure 2).

\section{Discussion}

The use of historical records is a valuable tool for the modeling of elusive species ( $e$. g. Wilting et al. 2010; Jenks et al. 2012). Besides the four historical records used in this research, there is no further information available to support the historical distribution of the margay in Northeastern Mexico. There have been some efforts to determine the

Table 2. Predictive variables for the generation of the distribution model of L. wiedii in Northeastern Mexico.

\begin{tabular}{lcc}
\hline \multicolumn{1}{c}{ Variable } & Contribution (\%) & Cumulative contribution \\
\hline Precipitation of wettest quarter & 57.9 & 57.9 \\
Vegetation type & 12.4 & 70.3 \\
Elevation & 11.4 & 81.7 \\
Topographic index & 6.3 & 88.0 \\
Annual precipitation & 2.5 & 90.5 \\
Slope & 2.3 & 92.8 \\
Mean temperature of the wettest quarter & 1.6 & 94.4 \\
\hline
\end{tabular}




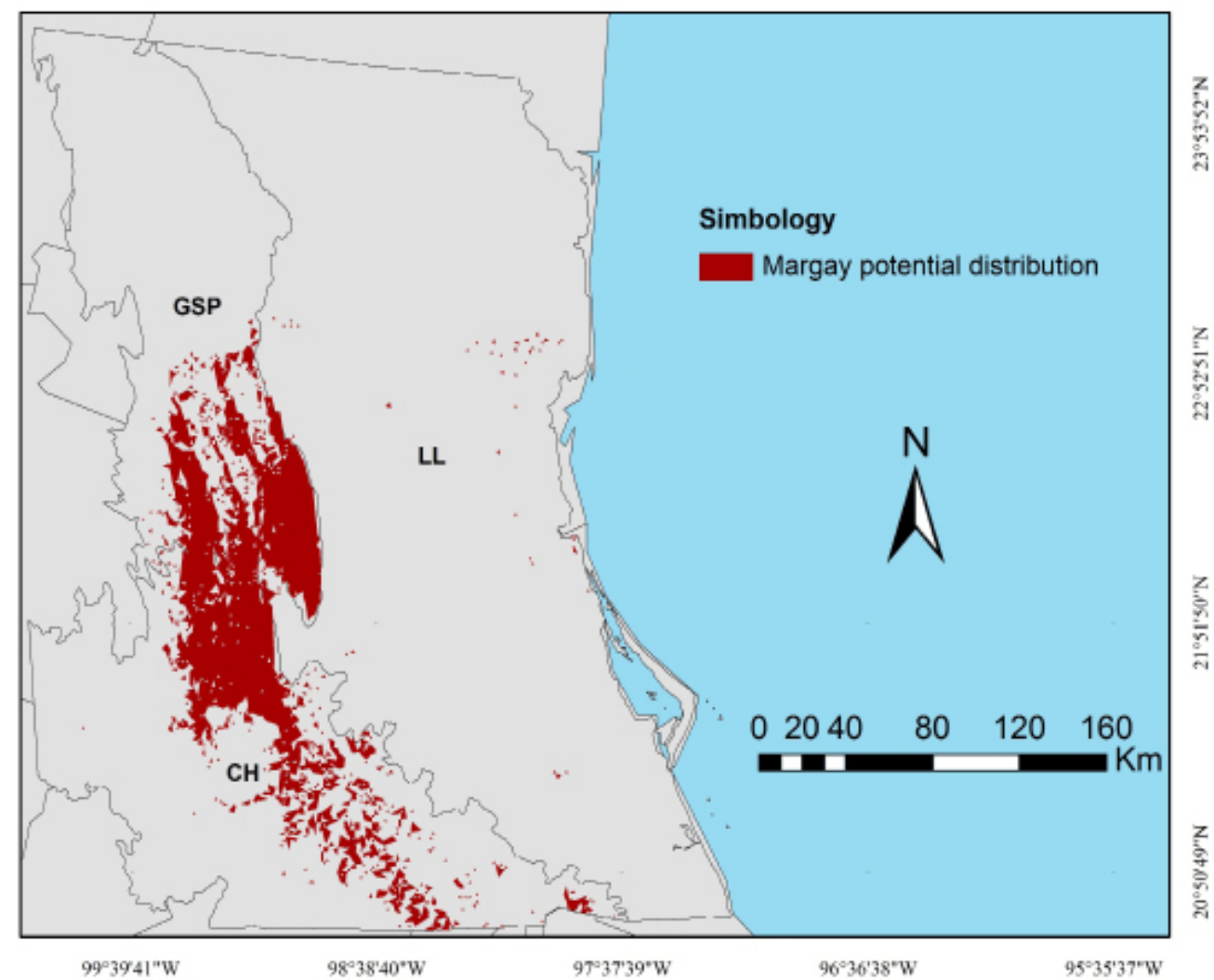

Figure 2. Map of potential distribution of the margay in Northeastern Mexico.

distribution area using only these records, which has prompted the creation of maps that lack validity, such as those proposed by Hall 1981 and Aranda (2005).

In this study, we obtained a robust model based on the value of AUC according to Araujo and Guisan (2006). The most relevant variables that explain the potential distribution of the margay coincided with climatic fluctuation (Guggisberg 1975; Bisbal 1989; Azevedo 1996; Oliveira 1998). Moreover, these same authors mention that this species inhabits tropical regions, where the presence of tropical rain forest is frequent. Yet this species has also been reported to be present in induced grassland ecotones (Mondolfi 1986; Oliveira 1994; Martínez-Calderas et al. 2012), as long as there is closed-canopy arboreal vegetation nearby (Vaughan 1983; Mondolfi 1986; Tello1986). Areas with the wettest climate conditions provide a better vegetation coverage, which was appropriate for the species in accordance with Bisbal (1989), Oliveira (1994), and Mondolfi (1986). This occurred in only $9.0 \%$ of the study area. Regarding altitude, this species is known to live at heights ranging from sea level to $1,100 \mathrm{~m}$ (Oliveira 1994), or even 3,000 $\mathrm{m}$ in the valleys of the Andes (Tello1986), meaning that these results fall within this range.

No reports have been produced to date that describe the relation between the presence of the margay and the topographic index or the slope range. However, the largest areas were located in mountainous localities of Sierra Madre Oriental, in the Southern portion of GSP, and in the Northern region of $\mathrm{CH}$. An important portion of these subprovinces maintains continuity in the area of the potential distribution of the margay. They also contain large and nearby patches, which may guarantee connectivity among populations. However most of the study area showed only small 
Table 3. Extension $\left(\mathrm{km}^{2}\right)$ of the portion of physiographic subprovinces (PSP) and percentage of potential distribution of the margay in Northeastern Mexico.

\begin{tabular}{lrrr}
\hline \multicolumn{1}{c}{ PSP } & Area $\left(\mathbf{k m}^{2}\right)$ & Potential distribution (\%) & Potential distribution $\left(\mathbf{k m}^{\mathbf{2}}\right)$ \\
\hline Gran Sierra Plegada & $16,929.3$ & 18.1 & 3064.2 \\
Llanuras y Lomerios & $45,851.8$ & 0.4 & 183.4 \\
Carso Huasteco & $21,742.0$ & 20.2 & 4391.9 \\
Total & $84,523.1$ & 9.0 & 7607.1 \\
\hline
\end{tabular}

isolated spots or areas with no potential distribution for the margay, especially in the portions of the flattest and driest terrains, mainly in LL.

Deforestation due to land-use change, mostly because of sugarcane cultivation or extensive ranching (Villordo-Galván et al. 2010), occupies a large portion of the study area. Crops (Jiménez et al. 2004) and induced grassland for cattle (Vieyra-Alberto et al. 2013) are established for the most part in flat or moderate slope terrains with deep soils. In this very fragmented landscape, remnants of closed vegetation exist only in terrains with steeper and often rough slopes, where neither agriculture nor livestock can occur (Guevara and Laborde 1999; Trejo and Dirzo 2000; Reyes-Hernández et al. 2007).

Habitat fragmentation alters the composition and structure of animal communities through the modification of ecological processes (v. gr. Wilcove 1985). In fragmented habitats, some populations tend to become isolated. The survival of the species depends on their ability to move between these patches, gaining access to the necessary resources, maintaining their genetic diversity, and keeping their reproductive capacity as a population (Petit et al. 1995; Buza et al. 2000). The species' sensitivity to change depends on its behavior and morphology (Wolff 1999; Laurance 1995; Buza et al. 2000; Nupp and Swihart 2000; Gehring and Swihart 2004), as well as on the availability of landscape elements (Gehring 2000). It is known that density of predators and, consequently, potential prey vulnerability is higher in small patches (Wilcove 1985; Andren 1992). Size can influence the area of activity and the possibility of moving within it (Gehring and Swihart 2004). Previous studies suggest that animals, even those extremely mobile, avoid passing through altered areas of habitat (Smallwood 1994; Machtans et al. 1996). For this reason, if there are gaps in the connection between two or more small populations, local extinctions can occur (v. gr. Beier 1993).

Among predators, the larger they are the bigger areas they require, which is why they are more susceptible to become locally extinct due to habitat loss. Moreover, in fragmented habitats conflicts with humans are more frequent (e.g. Crooks and Soule 1999). Medium and small-sized carnivore populations such as the margay are often benefited by the decline of top predators and increase their numbers (Prugh et al. 2009; Oliveira et al. 2010). This produces a decrease in the population size of prey. Since the area of activity of a predator is in accordance with prey availability, fragmentation tends to create a general imbalance (Oehler and Litvaitis 1996). The area of activity of a predator is in accordance with prey availability. Thus, species of this kind are susceptible to fragmentation, and above all, to the size of the patch, which must maintain the adequate habitat conditions in order to improve the continuity of the species (e. g. Gehring and Swihart 2004). Studies mention that the Margay populations are negatively impacted by ocelot (through 'the ocelot effect' (Oliveira et al. 2010). However, both species are usually sympatric, and can share 
habitat and distributional range. Compared to the potential distribution ocelot (Martínez-Calderas et al. 2015), the margay was less extensive in this subprovinces. For example, in LL is wider the presence of the ocelot, mainly to the northeast of this region. Margay is present only in small isolated patches.

The disappearance of natural ecosystems is inherent to the encroachment in anthropogenic activities, especially in agricultural production. Sahagún-Sánchez et al. (2011) estimated that $13 \%$ of the remaining vegetation coverage in the study area is in risk. In general, road density and size of human population are important variables related to fragmentation (Laurance et al. 2002). For example, roads are significant landscape modifications and are considered deforestation agents that accelerate fragmentation, reduce the regeneration of the forests, and are a threat for many tropical ecosystems and for the distribution of specialized species (e. g. Young 1994; Fearnside 2007; Freitas et al. 2010). They frequently increase slope instability, they allow the unregulated extraction of natural resources and the transformation of the landscape (Young 1994). The new Rioverde-Cd. Valles highway goes through $\mathrm{CH}$ and GSP in the areas with the best potential habitat for margays, which poses a new threat. Roads and related disturbances have a noticeable and well-recorded impact on wild felines (Van Dyke et al. 1986; Beldon and Hagedorn 1993; Beier 1995; Lovallo and Anderson 1996; Tewes and Blanton 1998; Tuovila 1999; Tewes and Hughes 2001). Unless there are more efforts to improve the design, construction and maintenance of the roads, as well as to understand and mitigate their effects, several carnivore species (e. g. Noss et al. 1996; Ruediger 1996), and specialized montane forest biota (Young 1994) may decline or disappear.

For this study, the reliable distribution area of the presence of margays was restricted to the Northeastern portion of its global distribution. It is crucial to stress the importance of preserving the landscape structure as along with the juxtaposition of spatial elements and connectivity for the conservation of species (e. g. Danielson 1994; Gehring 2000). Conservation must begin with habitat protection and restoration (e. g. Danielson 1994; Fahrig 1997), so the connection between GSP and CH is of vital importance to the preservation of margays in the long term. One alternative to mitigate some of the effects of fragmentation, and to compromise with the need for agricultural production, is the plantation of forests with non-native species. This can also aid in the conservation of some non-flying mammals, thus collaborating in the conservation of the local biodiversity (Martin et al. 2012). In this sense, fruit gardens or timberlands may be more suitable than annual crops because they provide better habitat for adaptable species, including margays. Furthermore, these new farming areas could use native vegetation as a buffer zones.

This study provides enough accurate information regarding the fundamental aspects of the habitat and essential needs of the margay to lay the foundation of an effective management plan in Northeastern Mexico. The involvement of government entities and the public is essential for the implementation of these new management plans. Conserving this carnivore will also improve the conservation of many other valuable species, as well as their ecosystem and environmental services.

\section{Acknowledgments}

We thank the Mexican National Council of Science and Technology (CONACyT) for their support during the execution of fieldwork between 2006 and 2009, as well as 
the Colegio de Postgraduados for their support in the same area between 2010 and 2012. We also thank I. Palacio-Ayala for her support in the manuscript.

\section{Literature Cited}

Anderson, R. P., D. Lew, and A. T. Peterson. 2003. Evaluating predictive models of species' distributions: criteria for selecting optimal models. Ecological Modelling 162:211-232.

AndRen, H. 1992. Corvid density and nest predation in relation to forest fragmentation, a landscape perspective. Ecology 73:794-804.

Aranda, M. 2005. Margay. Pp. 361-362 in Los Mamíferos Silvestres de México (Ceballos, G., y G. Oliva eds.). Fondo de Cultura Económica / CONABIO. México.

Araujo, M. B., and A. Guisan. 2006. Five (or so) challenges for species distribution modelling. Journal of Biogeography 33:1677-1688.

Azevedo, F. C. C. DE. 1996. Notes on the behavior of the margay Felis wiedii (Schinz, 1821), (Carnivora, Felidae), in the Brazilian Atlantic Forest. Mammalia 60:325-328.

Beler, P. 1993. Determining minimum habitat areas and habitat corridors for cougars. Conservation Biology 7:94-108.

Beier, P. 1995. Dispersal of juvenile cougars in fragmented habitat. Journal of Wildlife Management 59:228-237.

Beldon, B. C., AND B. W. Hagedorn. 1993. Feasibility of translocating panthers into northern Florida. Journal of Wildlife Management 57:388-397.

Bisbal, F. J. 1989. Distribution and habitat association of the carnivores in Venezuela. Pp. 339-362 in Advances in Neotropical Mammalogy (Redford, K. H., and J. F. Eisenberg, eds.). Sandhill Crane Press. Gainesville, U. S. A.

Burneo, S., J. F. González-Maya, And D. TiRIRA. 2009. Distribution and habitat modelling for Colombian weasel Mustela felipei in the Northern Andes. Small Carnivore Conservation 41:41-45.

Buza, L., A. Young, And P. Thrall. 2000. Genetic erosion, inbreeding and reduced fitness in fragmented populations of the endangered tetraploid sea Swaisona recta. Biological Conservation 93:177-186.

Ciat (Centro Internacional de Agricultura Tropical), Unep (United Nations Environment Program), Ciesin (Center for International Earth Science Information Network), Columbia University, AND The World Bank. 2005. Latin American and Caribbean Population Data Base. Version 3. Available at http://www.na.unep.net/datasets/datalist.php3. 11 July 2014.

Contreras-Medina, R., I. Luna-Vega, and C. A. Ríos-Muñoz. 2010. Distribución de Taxus globosa (Taxaceae) en México: Modelos ecológicos de nicho, efectos del cambio del uso de suelo y conservación. Revista Chilena de Historia Natural 83:421-433.

CRooks, K. R., AND M. E. SoulÉ. 1999. Mesopredator release and avifaunal extinctions in a fragmented system. Nature 400:563-566.

Danielson, B. J. 1994. A justification for the conservation of large reserves. Pp. 276-277 in Principles of Conservation Biology (Meffe, K., and C. R. Carroll eds.). Sinauer, Sunderland, U. S. A..

Elith, J., C. H. Graham, R. P. Anderson, M. Dudik, L. G. Lohmann, B. A. Loiselle, G. Manion, C. Moritz, M. Nakamura, Y. Nakazawa, J. Overton, A. T. Mcc, A. T. Peterson, S. J. Phillips, K. S. Richardson, K. S. Scachetti-Pereira, R. E. Schapire, J. Soberon, S. Williams, M. S. Wisz, AND N. E. Zimmermann. 2006. Novel methods improve prediction of species distribution from occurrence data. Ecography 29:129-151.

EsRI. 2006. ArcGIS Desktop 9.2. Environmental System Research Institute. California, U. S. A. FAHRIG, L. 1997. Relative effects of habitat loss and fragmentation on population extinction. Journal of Wildlife Management 61:603-610. 
Fearnside, P. M. 2007. Brazil's Cuiabá-Santarém (BR-163) highway: the environmental cost of paving a soybean corridor through the Amazon. Environmental Management 39:601-614.

Ferrier, S., ANd A. Guisan. 2006. Spatial modelling of biodiversity at the community level. Journal of Applied Ecology 43:393-404.

Freitas, S. R., T. J. Hawbaker, and J. P. Metzger. 2010. Effects of roads, topography, and land use on forest cover dynamics in the Brazilian Atlantic Forest. Forest Ecology and Management 259:410-417.

GBIF. 2014. Global Biodiversity Information Facility. Available at: http://www.gbif.org/. 05 July 2014.

Gehring, T. M. 2000. Ecology of mammalian predators in a landscape fragmented by agriculture. Doctoral dissertation. Universidad Purdue. West Lafayette, U. S. A.

Gehring, T. M., AND R. K. Swihart. 2004. Home range and movements of long-tailed weasels in a landscape fragmented by agriculture. Journal of Mammalogy 85:79-86.

Guevara, S., AND J. Laborde. 1999. Historia del paisaje de la sierra de Los Tuxtlas, Veracruz (México). Pp. 44-64 in Diversidad biológica y cultural rural: en la gestión ambiental de desarrollo (Pineda, F. D., J. M. de Miguel, and M. A. Casado eds.). Mundiprensa y Multimedia Ambiental. Madrid, España.

GuggisBerg, C. A. W. 1975. Wild cats of the world. Taplinger Publishing Company. New York, U.S.A.

HaLl, E. R. 1981. The mammals of North America. 2nd edition. John Wiley \& Sons. New York, U.S. A.

Hansen, M. R. Defries, J. R. G. Townshend, and R. Sohlberg. 2000. Global land cover classification at $1 \mathrm{~km}$ resolution using a decision tree classifier. International Journal of Remote Sensing 21:1331-1365.

Hernandez, P. A., C. H. Graham, L. L. Master, and D. L. Albert. 2006. The effect of sample size and species characteristics on performance of different species distribution modeling methods. Ecography 29:773-785.

Hijmans, R. J., S. E. Cameron, J. L. Parra, P. G. Jones, and A. Jarvis. 2005. Very high resolution interpolated climate surfaces for global land areas. International Journal of Climatology 25:1965-1978.

INEGI. 2002a. Síntesis de información geográfica del estado de San Luis Potosí. Instituto Nacional de Geografía e Informática. Aguascalientes, México.

INEGI. 2002b. Conjunto de datos Vectoriales de Vías de transporte y comunicación de las cartas vectoriales topográficas escala 1:250,000, Serie II, Continuo Nacional. Instituto Nacional de Estadística, Geografía e Informática. Aguascalientes, México.

INEGI. 2005. Conjunto de datos Vectoriales de la Carta de Uso del Suelo y Vegetación, Escala 1:250,000, Serie III, Continuo Nacional. Instituto Nacional de Estadística, Geografía e Informática. Aguascalientes, México.

INEGI. 2008. Continuo de Elevación Nacional. Instituto Nacional de Geografía e Informática. Aguascalientes, México. Available at http://mapserver.inegi.org.mx. 11 june 2012.

INEGI. 2011. Cartas geográficas de clima, suelo y precipitaciones, escala 1:250,000. Instituto Nacional de Estadística, Geografía e Informática (INEGI). Aguascalientes, México.

Jenks, K. E., S. Kitamura, A. J. Lynam, D. Ngoprasert, W. Chutipong, R. Steinmetz, R. Sukmasuang, L. I. Grassman Jro, T. Cutter, N. Tantipisanuh, N. Bhumpakphan, G. A. Gale, D. H. Reed, P. Leimgruber, and N. Songsasen. 2012. Mapping the distribution of dholes, Cuon alpinus (Canidae, Carnivora), in Thailand. Mammalia 76:175-184.

Jiménez, C. A., V. T. Vargas, W. E. Salinas, M. Aguirre, and D. Rodríguez. 2004. Aptitud agroecológica para el cultivo de la caña de azúcar en el sur de Tamaulipas, México. Investigaciones Geográficas, Boletín del Instituto de Geografía UNAM 53:58-74.

Kareiva, P., and U. Wennergren. 1995. Connecting landscape patterns to ecosystems and population processes. Nature 373: 299-302 
LaURANCE, W. F. 1995. Extinction and survival of rainforest mammals in a fragmented tropical landscape. Pp. 46-63 in Landscape Approaches in Mammalian Ecology and Conservation. (Lidicker Jr., W. Z. ed.). University of Minnesota Press. Minneapolis, U. S. A.

Laurance, W. F., A. K. M. Albernaz, G. Schroth, P. M. Fearnside, S. Bergen, E. M. Venticinque, AND C. Costa. 2002. Predictors of deforestation in the Brazilian Amazon. Journal of Biogeography 29:737-748.

Lovallo, M. J., AND E. M. Anderson. 1996. Bobcat movements and home ranges relative to roads in Wisconsin. Wildlife Society Bulletin 24:71-76.

Machtans, C. S., M. A. Villard, and S. J. Hannon. 1996. Use of riparian buffers strips as movement corridors by forest birds. Conservation Biology 10:1377-1379.

Marino, J., M. Bennett, D. Cossios, A. Iriarte, M. Lucherini, P. Pliscoff, C. Sillero-Zubiri, L. Villalba, and S. Walker. 2011. Bioclimatic constrains to Andean cat distribution: a modeling application for rare species. Diversity and Distributions 17:311-322.

Martin, P. S., C. Gheler-Costa, P. C. Lopes, L. M. Rosalino, and L. M. Verdade. 2012. Terrestrial non-volant small mammals in agro-silvicultural landscapes of Southeastern Brazil. Forest Ecology and Management 282:185-195.

Martínez-Calderas, J. M., O. C. Rosas-Rosas, J. Palacio-Núñez, J. F. Martínez-Montoya, and J. A. Villordo-Galván. 2012. Nuevos registros de tigrillo (Leopardus wiedii) en San Luis Potosí, México. Acta Zoológica Mexicana (n. s.) 28:482-486.

Martínez-Calderas, J. M., O. C. Rosas-Rosas, J. Palacio-Núñez, J. F. Martínez-Montoya, G. Olmos-Oropeza and L. A. Tarango-Arámbula. 2015. Potential distribution of the ocelot (Leopardus pardalis) in Northeastern Mexico. Therya 6:545-558.

Mondolfı, E. 1986. Notes on the biology and status of the small wild cats in Venezuela. Pp. 25-146 in Cats of the world: biology, conservation, and management (Miller, S. D., and D. D. Everett, eds.). National Wildlife Federation. Washington, U. S. A.

Noss, R. F., H. B. Quigley, M. G. Hornocker, T. Merrill, and P. C. Paquet. 1996. Conservation biology and carnivore conservation in the Rocky Mountains. Conservation Biology 10:949-963.

Nupp, T. E., AND R. K. SwiHART. 2000. Landscape-level correlates of small mammal assemblages in forest fragments of farmland. Journal of Mammalogy 81:512-526.

Oenler, J. M., AND J. A. Litvaitis. 1996. The role of spatial scale in understanding responses of medium-sized carnivores to forest fragmentation. Canadian Journal of Zoology 74:2070-2079.

Oliveira, T. G. De, M. A. Tortato, L. Silveira, C. B. Kasper, F. D. Mazim, M. Lucherini, A. T. Jácomo, J. B. G. Soares, R. V. Marques, and M. E. Sunquist. 2010. Ocelot ecology and its effect on the small-felid guild in the lowland neotropics. Pp. 559-580 in Biology and conservation of wild cats (Macdoweld, D. W., and A. J. Loveridge, eds.). Oxford University Press. Oxford, United Kindom.

Oliveira, T. G. De. 1994. Neotropical cats: ecology and conservation. Edufma. Sao Luís, Brasil.

Oliveira, T. G. De. 1998. Leopardus wiedii. Mammalian Species 579:1-6.

Payan, E., E. Eizirik, T. G. De Oliveira, R. Leite-Pitman, M. Kelly, and C. Valderrama. 2008. Leopardus wiedii. UICN 2013. UICN Red List of Threatened Species. Version 2013.1. Available at http://www.iucnredlist.org. 04 August 2013.

Pearson, R. G., C. J. Raxworthy, M. Nakamura, and A. T. Peterson. 2007. Predicting species distributions from small numbers of occurrence records: a test case using cryptic geckos in Madagascar. Journal of Biogeography 34:102-117

Petit, L. J., D. R. Petit, And T. E. Martin. 1995. Landscape-level management of migratory birds: looking past the trees to see the forest. Wildlife Society Bulletin 23:420-429.

Phillips, S. J., R. P. Anderson, And R. E. Schapire. 2006. Maximum entropy modeling in species geographic distributions. Ecological Modeling 190:231-259.

Phillips, S. J., M. Dudík, And R. E. Schapire. 2004. A maximum entropy approach to species distribution modeling. Pp. 655-662 in Proceedings of the 21st International 
Conference on Machine Learning (Greiner, R., and D. Schuurmans eds.). ACM Press. New York, U. S. A.

Prugh, L. R., C. J. Stoner, C. W. Epps, W. T. Bean, W. J. Ripple, A. S. Laliberte, and J. S. Brashares. 2009. The rise of the mesopredator. BioScience 59:779-791.

Reyes-Hernández, H., M. Aguilar-Robledo, J. R. Aguirre-Ribera, M. Silva-Aparicio, and I. R. TrejoVÁzQuez. 2007. Caracterización de remanentes arbóreos y razones de su permanencia en el área del proyecto Pujal-Coy, San Luis Potosí, México. Pp. 85-104 in Corredores biológicos: acercamiento conceptual y experiencias en América (Chassot, O., and C. Morera, eds.). Centro Científico Tropical, Universidad Nacional de Costa Rica/Escuela de Ciencias Geográficas. Instituto Panamericano de Geografía e Historia. Imprenta Nacional de Costa Rica.

RUEDIGER, B. 1996. The relationship between rare carnivores and highways. Proceedings of the Florida Department of Transportation/Federal Highway Administration Transportation-related Wildlife Mortality Seminar, April 30-May 2, 1996. U. S. Department of Transportation. Federal Highway Administration. FHWA-PD-96-041, Washington, U.S. A.

Sahagún-Sánchez, F. J., H. Reyes-Hernández, J. L. Flores-Flores, and L. Chapa-Vargas. 2011. Modelización de escenarios de cambio potencial en la vegetación y el uso de suelo en la Sierra Madre Oriental de San Luis Potosí, México. Journal of Latin American Geography 10:65-86.

SEMARNAT. 2010. NOM-059-SEMARNAT-2010. Protección ambiental-Especies nativas de México de flora y fauna silvestres-Categorías de riesgo y especificaciones para su inclusión, exclusión o cambio-Lista de especies en riesgo. Diario oficial de la federación. Ciudad de México, México.

Smallwood, K. S. 1994. Trends in California mountain lion populations. The Southwestern Naturalist 39:67-72.

TelLo, J. L. 1986. The situation of the wild cats (Felidae) in Bolivia. Report prepared for CITES Secretariat. Lausane, Switzerland.

TeWes, M. E., AND D. R. Blanton. 1998. Potential impacts of international bridges on ocelots and jaguarundis along the Rio Grande wildlife corridor. Pp. 135-139 in Proceedings of the International Conference on Wildlife Ecology and Transportation (FL-ER-69-98) (Evink, G. L., P. Garrett, D. Zeigler, and J. Berry, eds.). Florida Department of Transportation. Tallahassee, Florida.

Tewes, M. E., AND R. W. ughes. 2001. Ocelot management and conservation along transportation corridors in Southern Texas. Pp. 559-564 in Proceedings of the 2001 International Conference on Ecology and Transportation (Irwin, C. L., P. Garrett and K. P. McDermott, eds.). Center for Transportation and the Environment, North Carolina State University Keystone, Co. 24-28 September 2001.

Tewes, M. E., AND D. J. Schmidry. 1987. The neotropical felids: jaguar, ocelot, margay, and jaguarondi. Pp. 697-711 in Wild furbearer management and conservation in North America (Novak, M., J. A. Baker, M. E. Obbard and B. Malloch, eds.). Ontario Ministry of Natural Resources. Toronto, Canada.

Trejo, I., AND R. DiRzo. 2000. Deforestation of seasonally dry tropical forest: a national and local analysis in Mexico. Biological Conservation 94:133-142.

TuoviLA, V. R. 1999. Bobcat and ocelot movements and survival near US Highway 281. Master Science Tesis, Texas A\&M University. Arlington, U. S. A.

Van Dyke, F. G., R. H. Brocke, and H. G. Shaw. 1986. Use of road track counts as indices of mountain lion presence. Journal of Wildlife Management 50:102-109.

Vaughan, C. 1983. A report on dense forest habitat for endangered wildlife species in Costa Rica. National University, Heredia. Costa Rica.

Vieyra-Alberto, R., I. A. Domínguez-Vara, G. Olmos-Oropeza, J. F. Martínez-Montoya, J. L. Borquez-Gastelum, J. Palacio-Núñez, J. A. Lugo de la Fuente, and E. Morales-Almaráz. 
2013. Perfil e interrelación mineral en agua, forraje y suero sanguíneo de bovinos durante dos épocas en la Huasteca Potosina, México. Agrociencia 47:121-133.

Villordo-Galván, J. A., O. C. Rosas-Rosas, J. F. Martínez-Montoya, F. Clemente-Sánchez, L. A. Tarango-Arámbula, M. D. Sánchez-Hermosillo, and L. C. Bender. 2010. The jaguar (Panthera onca) in San Luis Potosi, Mexico. The Southwestern Naturalist 55:394-402.

WILCOVE, D.S. 1985. Nest depredation in forest tracts and the decline of migratory songbirds. Ecology 66:1211-1214.

Wilting, A., A. Cord, A. J. Hearn, D. Hesse, A. Mohamed, C. Traeholdt, S. M. Cheyne, S. Sunarto, M. Jayasilan, J. Ross, A. C. Shapiro, A. Sebastian, S. Dech, C. Breitenmoser, J. Sanderson, J. W. Duckworth, AND H. Hofer. 2010. Modelling the species distribution of flat-headed cats (Prionailurus planiceps), an endangered South-east Asian small felid. PLoS ONE 5: :e9612.

Wolff, J. O. 1999. Behavioral model systems. Pp. 11-40 in Landscape ecology of small mammals (Barrett, G. W., and J. D. Peles, eds.). Springer-Verlag. NewYork, U. S. A.

Young, K. R. 1994. Roads and the environmental degradation of tropical montane forests. Conservation Biology 8:972-97658.

Submited: November 27, 2015

Reviewed: April 1, 2016

Accepted: May 4, 2016

Associated editor: Jesus Maldonado 


\section{Appendix 1}

Information about margay records in Northeastern Mexico. Source of records: Historic records: 1. Louisiana State university Museum of Zoology (LSUMZ), 2. Colección de Mastozoología del ENCB-IPN, 3. Colección de Mamíferos del Museo de Zoología Alfonso L. Herrera. Facultad de Ciencias, UNAM (MZFC-UNAM). Records from literature: 4. Are of Martínez-Calderas et al. 2012. Field work and surveys: 5. Camera traps and 6. Tracks and signs. Longitude = Long, Latitude $=$ Lat, $\%$ of vegetation cover $=\mathrm{Cv}$, elevation in meters $=\mathrm{Ev}$, degree of slope $=\mathrm{S}$. PSP $=$ physiographic subprovinces: $\mathrm{CH}=$ Carso Huasteco, GSP = Gran Sierra Plegada.

\begin{tabular}{|c|c|c|c|c|c|c|c|c|}
\hline \multirow[b]{2}{*}{ No. } & \multirow[b]{2}{*}{ Long } & \multirow[b]{2}{*}{ Lat } & \multirow[b]{2}{*}{ PSP } & \multirow[b]{2}{*}{ Source } & \multicolumn{2}{|l|}{ Vegetation } & \multicolumn{2}{|c|}{ Terrain } \\
\hline & & & & & Type & Cv & Ev & $\mathbf{S}$ \\
\hline 1 & -99.009 & 21.393 & $\mathrm{CH}$ & 1 & Oak forest & 89 & 1147 & 15 \\
\hline 2 & -98.824 & 21.229 & $\mathrm{CH}$ & 1 & Tropical rain forest & 79 & 507 & 5 \\
\hline 3 & -99.498 & 22.504 & GSP & 2 & Oak forest & 95 & 1078 & 10 \\
\hline 4 & -99.088 & 21.186 & $\mathrm{CH}$ & 3 & Clouded forest & 90 & 1145 & 37 \\
\hline 5 & -99.441 & 22.465 & GSP & 4 & Oak forest & 80 & 1557 & 25 \\
\hline 6 & -99.441 & 22.465 & GSP & 4 & Oak forest & 80 & 1557 & 25 \\
\hline 7 & -98.965 & 22.100 & GSP & 4 & Tropical deciduous forest & 89 & 230 & 3 \\
\hline 8 & -99.166 & 21.828 & $\mathrm{CH}$ & 4 & Tropical deciduous forest & 80 & 300 & 50 \\
\hline 9 & -98.899 & 21.918 & GSP & 4 & Tropical deciduous forest & 98 & 315 & 3 \\
\hline 10 & -99.400 & 22.062 & $\mathrm{CH}$ & 4 & Oak forest & 100 & 789 & 0 \\
\hline 11 & -99.402 & 22.070 & $\mathrm{CH}$ & 4 & Tropical forest & 97 & 904 & 13 \\
\hline 12 & -99.385 & 22.095 & $\mathrm{CH}$ & 4 & Oak forest & 90 & 809 & 5 \\
\hline 13 & -99.397 & 22.103 & $\mathrm{CH}$ & 4 & Tropical forest & 98 & 800 & 4 \\
\hline 14 & -99.386 & 22.094 & $\mathrm{CH}$ & 4 & Oak forest & 100 & 812 & 8 \\
\hline 15 & -99.401 & 22.098 & $\mathrm{CH}$ & 4 & Tropical forest & 100 & 904 & 5 \\
\hline 16 & -99.382 & 22.083 & $\mathrm{CH}$ & 4 & Tropical forest & 96 & 972 & 2 \\
\hline 17 & -99.416 & 21.895 & $\mathrm{CH}$ & 4 & Tropical forest & 90 & 775 & 0 \\
\hline 18 & -99.144 & 21.471 & $\mathrm{CH}$ & 4 & Clouded forest & 100 & 1157 & 20 \\
\hline 19 & -99.007 & 21.490 & $\mathrm{CH}$ & 4 & Tropical forest & 97 & 140 & 28 \\
\hline 20 & -98.992 & 21.488 & $\mathrm{CH}$ & 4 & Tropical rain forest & 100 & 320 & 17 \\
\hline 21 & -98.901 & 22.069 & GSP & 4 & Tropical forest & 100 & 488 & 38 \\
\hline 22 & -99.350 & 22.415 & GSP & 4 & Oak forest & 85 & 775 & 8 \\
\hline 23 & -98.964 & 22.152 & GSP & 4 & Tropical desiduos forest & 98 & 211 & 15 \\
\hline 24 & -99.062 & 21.306 & $\mathrm{CH}$ & 4 & Tropical rain forest & 97 & 1508 & 43 \\
\hline 25 & -98.884 & 21.266 & $\mathrm{CH}$ & 4 & Tropical rain forest & 92 & 985 & 45 \\
\hline 26 & -99.060 & 21.603 & $\mathrm{CH}$ & 4 & Tropical forest & 90 & 468 & 20 \\
\hline 27 & -99.137 & 21.789 & $\mathrm{CH}$ & 4 & $\begin{array}{l}\text { Induced grassland - } \\
\text { Tropical forest }\end{array}$ & 88 & 326 & 0 \\
\hline 28 & -99.017 & 21.565 & $\mathrm{CH}$ & 4 & Tropical rain forest & 97 & 1020 & 15 \\
\hline 29 & -98.756 & 21.351 & $\mathrm{CH}$ & 4 & Tropical rain forest & 95 & 152 & 10 \\
\hline 30 & -98.886 & 22.088 & GSP & 4 & Tropical deciduous forest & 97 & 480 & 47 \\
\hline 31 & -99.099 & 21.600 & $\mathrm{CH}$ & 4 & Tropical forest & 99 & 1195 & 41 \\
\hline 32 & -99.299 & 21.855 & $\mathrm{CH}$ & 4 & Tropical deciduous forest & 92 & 450 & 10 \\
\hline 33 & -99.448 & 22.496 & GSP & 4 & Oak forest & 100 & 1058 & 31 \\
\hline 34 & -99.471 & 22.491 & GSP & 4 & Oak forest & 96 & 1477 & 25 \\
\hline 35 & -99.108 & 21.501 & $\mathrm{CH}$ & 4 & Oak forest & 100 & 1160 & 25 \\
\hline 36 & -99.360 & 21.823 & $\mathrm{CH}$ & 4 & Oak forest & 89 & 628 & 5 \\
\hline 37 & -98.914 & 22.060 & GSP & 4 & Tropical desiduos forest & 93 & 515 & 6 \\
\hline
\end{tabular}




\begin{tabular}{rrrlllrrr}
38 & -99.036 & 22.151 & GSP & 4 & Tropical desiduos forest & 90 & 146 & 5 \\
39 & -98.947 & 22.016 & GSP & 4 & Tropical deciduous forest & 82 & 202 & 15 \\
40 & -99.036 & 22.240 & GSP & 4 & Tropical desiduos forest & 92 & 203 & 3 \\
41 & -98.939 & 22.211 & GSP & 5 & Tropical desiduos forest & 90 & 372 & 6 \\
42 & -98.942 & 22.223 & GSP & 5 & Tropical desiduos forest & 95 & 376 & 7 \\
43 & -98.959 & 22.239 & GSP & 5 & Tropical desiduos forest & 100 & 339 & 7 \\
44 & -98.933 & 22.287 & GSP & 5 & Tropical desiduos forest & 100 & 504 & 5 \\
45 & -98.968 & 22.303 & GSP & 5 & Tropical desiduos forest & 100 & 332 & 10 \\
46 & -98.977 & 22.360 & GSP & 5 & Tropical desiduos forest & 93 & 347 & 15 \\
47 & -98.963 & 22.365 & GSP & 5 & Tropical desiduos forest & 100 & 603 & 8 \\
48 & -98.961 & 22.280 & GSP & 5 & Tropical desiduos forest & 96 & 320 & 2 \\
49 & -98.958 & 22.163 & GSP & 5 & Tropical desiduos forest & 98 & 314 & 0 \\
50 & -98.967 & 22.221 & GSP & 5 & Tropical desiduos forest & 92 & 334 & 5 \\
51 & -98.963 & 22.174 & GSP & 5 & Tropical desiduos forest & 89 & 322 & 0 \\
52 & -99.020 & 21.439 & GH & 6 & Tropical forest-Acahual & 79 & 900 & 5 \\
53 & -99.289 & 22.441 & GSP & 6 & Tropical forest & 99 & 898 & 15 \\
\hline
\end{tabular}


POTENTIAL DISTRIBUTION OF MARGAY

256 THERYA Vol.7 (2):241-255 